\title{
ISLAMIC RULINGS ON WARFARE
}

\author{
Youssef $\mathrm{H}$. Aboul-Enein
}

Sherifa Zuhur

October 2004 